\title{
Chapter 38 \\ Pearl Production by Implantation of Outer Epithelial Cells Isolated from the Mantle of Pinctada fucata and the Effects of Blending of Epithelial Cells with Different Genetic Backgrounds on Pearl Quality
}

\author{
Masahiko Awaji, Takashi Yamamoto, Yasunori Iwahashi, Kiyohito Nagai, \\ Fumihiro Hattori, Kaoru Maeyama, Makoto Kakinuma, \\ Shigeharu Kinoshita, and Shugo Watabe
}

\begin{abstract}
In the current method of pearl production, the mantle fragment of a donor pearl oyster is transplanted into a host pearl oyster together with an inorganic bead (pearl nucleus). After this surgical procedure, only outer epithelial cells (OEC) in the transplanted mantle survive in a host pearl oyster and form a pearl sac to begin pearl formation. Therefore, implantation of only the OEC instead of the mantle fragment would be a possible alternative to the current procedure. To examine the potential of pearl production by implanting OEC in Pinctada fucata, we developed
\end{abstract}

\author{
M. Awaji $(\bowtie)$ \\ National Research Institute of Aquaculture, Japan Fisheries Research and Education Agency, \\ Minami-Ise, Japan \\ e-mail: awajim@affrc.go.jp \\ T. Yamamoto $\cdot$ Y. Iwahashi $\cdot$ K. Nagai \\ Pearl Research Laboratory, K. MIKIMOTO \& CO., LTD, Shima, Japan \\ e-mail:kenkyujo@mikimoto.com; y-iwahashi@mikimoto.com; k-nagai@mikimoto.com \\ F. Hattori · K. Maeyama \\ MIKIMOTO COSMETICS, Mie, Japan \\ e-mail: hattori.468@mikimoto-cosme.com; maeyama.511@mikimoto-cosme.com \\ M. Kakinuma \\ Graduate School of Bioresources, Mie University, Tsu, Mie, Japan \\ e-mail: kakinuma@bio.mie-u.ac.jp \\ S. Kinoshita \\ Department of Aquatic Bioscience, Graduate School of Agricultural and Life Sciences, \\ The University of Tokyo, Tokyo, Japan \\ e-mail: akino@mail.ecc.u-tokyo.ac.jp \\ S. Watabe \\ School of Marine Biosciences, Kitasato University, Minami, Sagamihara, Kanagawa, Japan \\ e-mail: swatabe@kitasato-u.ac.jp


a cell implantation method using the pearl nucleus carrying a small pit inoculated with OEC. As a result, approximately $70 \%$ of the inserted nuclei formed the nacreous layer when the OEC were inoculated at $5 \times 10^{4}$ cells/nucleus. Then, OEC isolated from two genetically different types of pearl oysters that significantly differed in shell nacre color (yellowness) were mixed at four different ratios, and the prepared OEC mixtures were transplanted to investigate the effects of the blend on the yellowness of pearls to be harvested. The yellowness of harvested pearls differed significantly in accordance with the mixing ratio. Similarly, OEC isolated from two types of pearl oysters that showed a significant difference in the thickness of their shell nacre aragonite tablets were mixed at four different ratios and transplanted. Mean thickness of the aragonite tablets of the harvested pearls differed according to mixing ratio. These results suggest the method to control pearl quality by blending OEC obtained from pearl oysters genetically improved by selective breeding for traits related to pearl quality.

Keywords Pearl oyster · Outer epithelial cells · Implantation · Blending · Yellowness $\cdot$ Aragonite tablets

\subsection{Introduction}

Currently, the method of pearl production using pearl oyster Pinctada fucata involves transplanting a small fragment of the mantle of a donor pearl oyster into a host pearl oyster together with a small shell bead called a pearl nucleus (Masaoka et al. 2013). After transplantation, only outer epithelial cells (OEC) in the transplanted mantle fragment survive in the host pearl oyster and form a pearl sac surrounding the pearl nucleus to begin pearl formation (Awaji and Suzuki 1995). Therefore, implantation of only OEC instead of the mantle fragment would be a possible alternative to the current pearl production procedure.

Quality of a pearl is determined by various traits: size, color, luster, shape, and blemish (Jerry et al. 2012; Atsumi et al. 2014). Among these traits, color is mainly developed by the amount of yellow pigments and the interference color of pearl nacre. The amount of yellow pigment in nacre is known to be largely affected by the genetic backgrounds of a donor pearl oyster (Wada 1985). The interference color is determined by thickness of the aragonite tablets of pearl nacre, which is also affected by the genetic backgrounds of a donor pearl oyster combined with water temperature and nutritional condition of a host pearl oyster (Linard et al. 2011; Muhammad et al. 2017; Odawara et al. 2017). Therefore, if we can produce pearls by implanting OEC, it might be possible to control yellowness or the interference color of pearls by blending the OEC isolated from donor pearl oysters with different genetic backgrounds regarding these traits.

To assess the possibility of these technical improvements in pearl production, we developed a method to produce pearls by implanting OEC and examined the effects of blending of OEC isolated from donor pearl oysters with different genetic backgrounds on the yellowness and interference color of pearls. 


\subsection{Materials and Methods}

\subsubsection{Implantation of a Pearl Nucleus with Outer Epithelial Cells into a Host Pearl Oyster}

OEC were separated from the mantle of a pearl oyster by the methods described in Awaji and Machii (2011). Briefly, a pallial zone of the pearl oyster mantle was excised out and washed in sterile balanced salt solution for marine mollusks (BSS, Awaji and Machii 2011) containing $1 \mathrm{mg} / \mathrm{ml}$ of kanamycin sulfate (11815-024, Thermo Fisher Scientific K.K., Yokohama, Japan) with several changes of the medium. Then the mantle strips were digested for $6 \mathrm{~h}$ at $25^{\circ} \mathrm{C}$ with a mixture of $1.25 \mathrm{mg} / \mathrm{ml}$ of dispase (17105-041, Thermo Fisher Scientific K.K.) and $0.5 \mathrm{mg} / \mathrm{ml}$ of collagenase (034-10533, Wako Pure Chemical Industries, Ltd., Osaka, Japan) in sterile BSS buffered at $\mathrm{pH} 7.5$ with $20 \mathrm{mM}$ HEPES (346-01373, Wako Pure Chemical Industries, Ltd.). After the digestion, the outer epithelium on an outer side of the mantle strip was carefully peeled off using forceps under a binocular microscope. The obtained outer epithelium was washed in the buffered BSS containing $0.4 \mathrm{mg} / \mathrm{ml}$ of hyaluronidase (151272, MP Biomedicals, LLC, Santa Ana, USA) to prepare suspension of the OEC clusters (Fig. 38.1a). Cell density was determined by staining cell nuclei with $0.1 \%$ crystal violet in $0.1 \mathrm{M}$ citric acid (Sanford et al. 1951). Briefly, precipitated cell clusters were incubated in $0.5 \mathrm{ml}$ of the crystal violet solution for $1 \mathrm{~h}$ at room temperature with agitation, and the number of cell nuclei stained dark blue with the dye was counted using a hemocyte counter. For pearl production, $1 \mu \mathrm{l}$ of OEC suspension $\left(1-5 \times 10^{4}\right.$ cells/ $\left.\mu \mathrm{l}\right)$ was inoculated into a small pit (1 mm diameter and $0.5-1.0 \mathrm{~mm}$ depth) of a pearl nucleus $(4.5 \mathrm{~mm}$ diameter, Fig. 38.1b), and the pearl nucleus was inserted into a host pearl oyster, as described in Awaji et al. (2014).
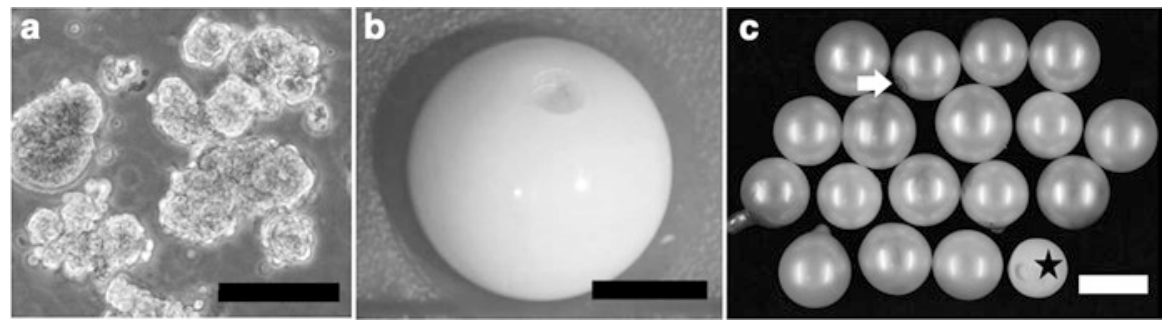

Fig. 38.1 Pearl formation by implanting outer epithelial cells isolated from a pearl oyster mantle. (a) Suspension of outer epithelial cell clusters prepared for implantation; (b) a pearl nucleus carrying a small pit; (c) pearls formed by the implantation of a pearl nucleus carrying a pit inoculated with outer epithelial cells. A white arrow indicates a dimple formed on the surface of a pearl at the site of a pit. A black star denotes a pearl nucleus harvested from a host oyster without pearl layers. Scale $=100 \mu \mathrm{m}(\mathbf{a}), 2 \mathrm{~mm}(\mathbf{b}), 5 \mathrm{~mm}(\mathbf{c})$ 


\subsubsection{Effects of the Blending of Outer Epithelial Cells on Yellowness of Pearls}

Several strains of $P$. fucata genetically different in shell nacre color have been maintained at Mikimoto Pearl Research Laboratory. Among these strains, strains Y and $\mathrm{W}$ are significantly different in yellowness of the shell nacre, strain $\mathrm{Y}$ being yellowish, while strain $\mathrm{W}$ being whitish. We used these two strains for the experiment. OEC isolated from these strains were blended at four different mixing ratios (Y:W $=3: 0,2: 1,1: 2,0: 3)$ and implanted for pearl production at $6.0 \times 10^{5}$ cells/nucleus. The host pearl oysters were reared in Ago Bay, Mie Prefecture, for 5 months until pearl harvesting. Yellowness of the harvested pearls was measured using a fast spectrophotometric color meter (CMS-35SP, Murakami Color Research Laboratory, Tokyo, Japan) and expressed as yellowness index (YI, YI=(1.250X-1.038Z)/Y), where $X, Y$, and $Z$ represent tristimulus values of CIE $1931 \mathrm{XYZ}$ color space, as described in Awaji et al. (2014).

\subsubsection{Effects of the Blending of Outer Epithelial Cells on the Thickness of the Pearls'Aragonite Tablets}

Strains YW and BWW are genetically different in terms of thickness of shell aragonite tablets, and the interference color of shell nacre differs between these strains. OEC were isolated from these strains and blended at the same ratios as in the experiment on yellowness. The blended cells were implanted for pearl production at $5.0 \times$ $10^{4}$ cells/nucleus. The host pearl oysters were reared in Ago Bay for 5 months until pearl harvesting. Thickness of the aragonite tablets of harvested pearls was calculated from the images obtained with a color 3D laser microscope (VK-9700, Keyence Corporation, Osaka, Japan) and a scanning electron microscope (S-2380N, Hitachi High Technologies Corporation, Tokyo, Japan) using VK-H1A1 software (Keyence Corporation) and ImageJ1.50-b, respectively.

\subsection{Results}

\subsubsection{Pearl Production by Implantation of Outer Epithelial Cells}

Nacreous pearls could be produced by the implantation of OEC, and the inoculation of $5 \times 10^{4}$ cells/nucleus led to formation of aragonite layers in approximately $70 \%$ of the inserted nuclei (Awaji et al. 2014). An example of the harvested pearls is shown in Fig. 38.1c. 


\subsubsection{Effects of the Blending of Outer Epithelial Cells on Yellowness of Pearls}

The harvested pearls were different in terms of yellowness (Fig. 38.2a). Blending of OEC from strains $\mathrm{Y}$ and $\mathrm{W}$ at the ratio of 2 to 1 (Y2+W1 in Fig. 38.2a, b) showed significantly higher yellowness than the 0 to 3 group (Y0+W3), and the 1 to 2 group (Y1+W2) was considered intermediate yellowness (Awaji et al. 2014). This result
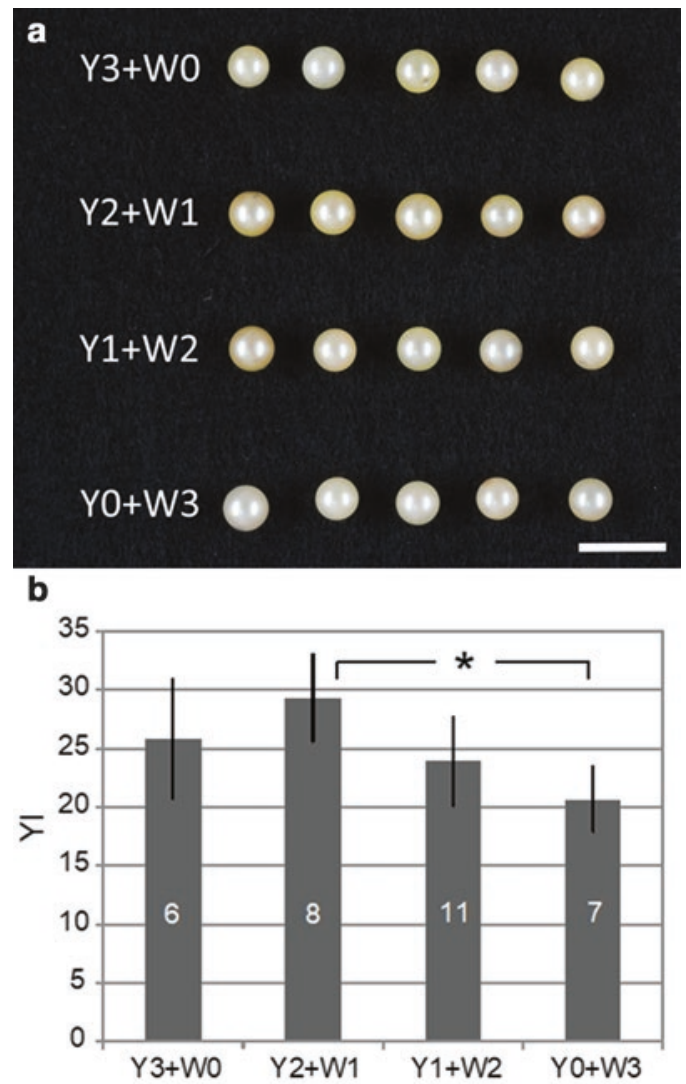

Fig. 38.2 Effects on the yellowness of harvested pearls of blending the outer epithelial cells isolated from two pearl oyster strains that significantly differed in shell nacre yellowness. The outer epithelial cells from the strains with yellow (Y) or white nacre (W) were mixed at four different ratios and transplanted into host oysters with the pearl nucleus carrying a pit. (a) A photograph showing difference in the yellowness of pearls harvested from four experimental groups. Scale $=10 \mathrm{~mm}$; (b) the yellowness of the pearls expressed by the yellowness index (YI). Numbers in the columns indicate the sample size, and bars indicate $95 \%$ confidence limits of the average. An asterisk indicates a significant difference (Steel-Dwass test, $p<0.05$ ). (Cited from Awaji et al. 2014) 
implied that we could modify the yellowness of pearls by the blending of OEC isolated from genetically different pearl oyster strains.

\subsubsection{Effects of the Blending of Outer Epithelial Cells on the Thickness of the Pearls'Aragonite Tablets}

Blending of OEC from strains YW and BWW caused difference in the thickness of the aragonite tablets of nacre. In the observations by scanning electron microscopy, implantation of OEC from strains YW and BWW at the blending ratio of 3 to 0 (YW3+BWW0) or 0 to 3 (YW0+BWW3) resulted in significant difference in the tablet thickness, and the groups with the blending ratio of 2 to 1 (YW2+BWW1) or 1 to 2 (YW1+BWW2) showed intermediate thickness (Fig. 38.3). The surface structure of the nacreous pearls could be observed clearly with a color 3D laser microscope. On this surface, a significant difference in the thickness of the aragonite tablets was observed in accordance with the mixing ratio, with the blended groups showing intermediate thickness. These results implied that we could modify the thickness of the aragonite tablets, namely, the interference color of the pearls, by the blending of OEC.

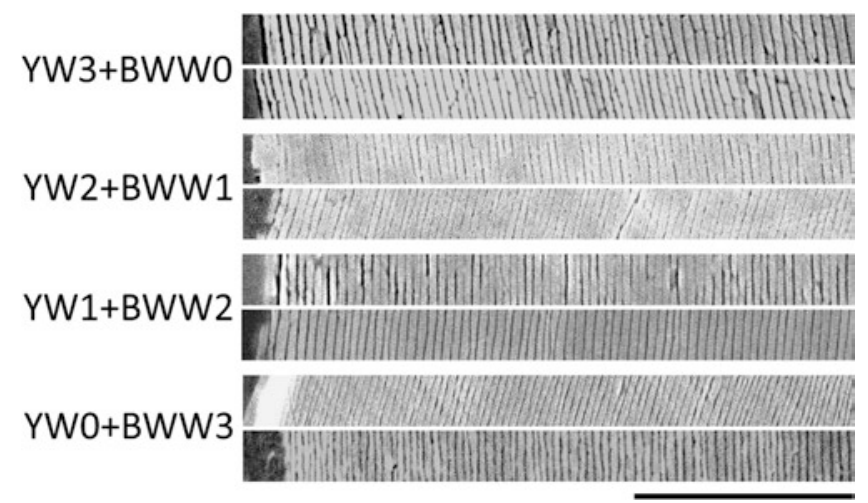

Fig. 38.3 Scanning electron microscopy images showing effects on the thickness of aragonite tablets in the pearl nacre of blending the outer epithelial cells isolated from two pearl oyster strains that significantly differed in the thickness of aragonite tablets of shell nacre. The outer epithelial cells from the strains with thick (YW) or thin (BWW) aragonite tablets were mixed at four different ratios and transplanted into host oysters with the pearl nucleus carrying a pit. Pearl surface is located to the left. Scale $=10 \mu \mathrm{m}$ 


\subsection{Discussion}

The obtained results indicate that we could modify the color of pearls by implanting blended OEC isolated from pearl oysters with genetically different phenotypes for pearl color traits. Intermediate phenotypes observed in the blended groups suggest that OEC isolated from two different strains can survive in a host pearl oyster to form a chimeric pearl sac after the implantation. Further studies to confirm the chimeric formation of a pearl sac by the blended OEC are needed, by using, for example, genomic DNA markers that can identify the origin of OEC (Masaoka et al. 2013). The practical use of the OEC implantation for pearl culture, however, is still challenging since a pit of a pearl nucleus remains as a dimple on the surface of a harvested pearl. OEC implantation methods without making a pit on a pearl nucleus are needed.

Pearl formation by the implantation of OEC would also serve to clarify mechanisms underlying shell and pearl formation at a molecular level in combination with gene transfection technologies. Various genes and molecules have been reported to be involved in shell formation, but details of their function have remained mostly unknown. Implantation of OEC transfected with a gene of interest for its overexpression would be a novel tool to analyze functions of the target gene. Gene transfection techniques effective for OEC are now under investigation.

For pearl oysters, breeding programs to develop superior donor and host pearl oyster strains are ongoing (Jerry et al. 2012; Wada 1985). The present studies became possible because several strains that exhibit different phenotypes for nacre color traits have been established through breeding programs. Although the use of pearl oyster strains showing different phenotypes for traits related to shell structures has been uncommon in shell formation studies, they would serve as novel tools for clarifying the mechanisms that underlie shell and pearl formation in detail.

Acknowledgment Part of this study was supported by JSPS KAKENHI Grant Numbers JP23658169, JP26292108, JP17K19282.

\section{References}

Atsumi T, Ishikawa T, Inoue N, Ishibashi R, Aoki H, Abe H, Kamiya N, Komaru A (2014) Postoperative care of implanted pearl oysters Pinctada fucata in low salinity seawater improves the quality of pearls. Aquaculture 422-423:232-238

Awaji M, Machii A (2011) Fundamental studies on in vivo and in vitro pearl formation - contribution of outer epithelial cells of pearl oyster mantle and pearl sacs. Aqua BioSci Monogr 4:1-39

Awaji M, Suzuki T (1995) The pattern of cell proliferation during pearl sac formation in the pearl oyster. Fish Sci 61:747-751 
Awaji M, Yamamoto T, Kakinuma M, Nagai K, Watabe S (2014) Pearl formation by transplantation of outer epithelial cells isolated from the mantle of pearl oyster Pinctada fucata. Nippon Suisan Gakkaishi 80:578-588 (in Japanese with English abstract)

Jerry DR, Kvingedal R, Lind CE, Evans BS, Taylor JJU, Safari AE (2012) Donor-oyster derived heritability estimates and the effect of genotype environment interaction on the production of pearl quality traits in the silver-lip pearl oyster, Pinctada maxima. Aquaculture 338-341:66-71

Linard C, Gueguen Y, Moriceau J, Soyez C, Hui B, Raoux A, Cuif JP, Cochard J-C, Le Pennec M, Le Moullac G (2011) Calcein staining of calcified structures in pearl oyster Pinctada margaritifera and the effect of food resource level on shell growth. Aquaculture 313:149-155

Masaoka T, Samata T, Nogawa C, Baba H, Aoki H, Kotaki T, Nakagawa A, Sato M, Fujiwara A, Kobayashi T (2013) Shell matrix protein genes derived from donor expressed in pearl sac of Akoya pearl oysters (Pinctada fucata) under pearl culture. Aquaculture 384-387:56-65

Muhammad G, Atsumi T, Sunardi KA (2017) Nacre growth and thickness of Akoya pearls from Japanese and hybrid Pinctada fucata in response to the aquaculture temperature condition in Ago Bay, Japan. Aquaculture 477:35-42

Odawara K, Ozaki R, Takagi M (2017) Influence of the thickness of the nacreous elemental lamina of the pearl oyster Pinctada fucata used as donor oysters on the pearls. Nippon Suisan Gakkaishi. https://doi.org/10.2331/suisan.16-00090 (in Japanese with English abstract)

Sanford KK, Earle WR, Evans VJ (1951) The measurement of proliferation in tissue culture by enumeration of cell nuclei. J Natl Cancer Inst 11:773-795

Wada KT (1985) The pearls produced from the groups of pearl oysters selected for color of nacre in shell for two generations. Bull Natl Res Inst Aquat 7:1-7 (in Japanese with English abstract)

Open Access This chapter is licensed under the terms of the Creative Commons Attribution 4.0 International License (http://creativecommons.org/licenses/by/4.0/), which permits use, sharing, adaptation, distribution and reproduction in any medium or format, as long as you give appropriate credit to the original author(s) and the source, provide a link to the Creative Commons license and indicate if changes were made.

The images or other third party material in this chapter are included in the chapter's Creative Commons license, unless indicated otherwise in a credit line to the material. If material is not included in the chapter's Creative Commons license and your intended use is not permitted by statutory regulation or exceeds the permitted use, you will need to obtain permission directly from the copyright holder.

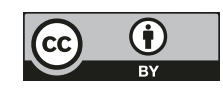

